al-Ihkam: Jurnal Hukum dan Pranata Sosial, 14 (2), 2019: 236-266

ISSN: 1907-591X, E-ISSN: 2442-3084

DOI: http://doi.org/10.19105/al-ihkam.v14i2.2396

\title{
Polygamy Marriage: Legal Culture, Optional Political Identity and Marital Status Dilemma (A Case Study in Pekalongan)
}

\author{
Shinta Dewi Rismawati \\ IAIN Pekalongan, Jl. Kusuma Bangsa No. 9 Pekalongan, 51141 \\ Email: shinta.dewi.rismawati@iainpekalongan.ac.id \\ Muhammad Abral Bin Abu Bakar \\ HELP University, No. 15, Jalan Sri Semantan 1, \\ Off Jalan Semantan, Bukit Damansara Kuala Lumpur, 50490
}

Article history: Received: 26 Juni 2019, Accepted: 12 Oktober 2019, Published: 4 Desember 2019

\begin{abstract}
:
Indonesian marriage law allows polygamy but with alternative and cumulative strict conditions. The novelty of this paper shows that the legal culture of polygamists is an important element that determines their optional political identity and marital status. This paper criticizes the legal culture in carrying out the polygamous marriages along with optional political identity and legal marital status of the actors. Qualitative research with the approach of social legal study was used to reveal the reality of polygamy among six couples. The findings and analysis show that the legal culture of the actors in either obeying or disobeying the rules of polygamy was subjective. However, the majority is diseobedient because they tend to break the rules, for instance by doing polygamy with sirri marriage. Sirri marriage is a political identity of life choice because of various considerations on both juridical and non-juridical ones. This condition has implications for the legal status dilemma of polygamous marriages. A marital status is considered legal only when the marriage is officially held and on the contrary, it is considered illegal in sirri condition. This polygamy marriage also has an impact on the legal status of the husband, wives and children in a family.
\end{abstract}

Author correspondence email: shinta.dewi.rismawati@iainpekalongan.ac.id Available online at: http:/ / ejournal.iainmadura.ac.id/index.php/alihkam/ Copyright (c) 2019 by al-ihkam. All Right Reserved 


\title{
Keywords:
}

Legal Culture; Legal Implications; Polygamy Marriage; Sirri Marriage; Optional Political Identity

\begin{abstract}
Abstrak:
Hukum Perkawinan di Indonesia memperbolehkan poligami tetapi dengan syarat ketat yang bersifat alternatif dan kumulatif. Kebaruan paper ini tampak dari fakta bahwa budaya hukum pelaku poligami merupakan elemen penting yang menentukan politik identitas pilihan dan status perkawinannya. Paper ini akan mengkritisi budaya hukum para pelaku dalam melangsungkan perkawinan poligaminya berikut politik identitas pilihan serta status hukum perkawinan yang dijalani. Penelitian kualitatif dengan pendekatan social legal studies digunakan untuk mengungkap realitas perkawinan poligami yang dilakukan oleh 6 pasangan keluarga. Temuan dan analisis menunjukkan bahwa budaya hukum para pelaku dalam mentaati atau tidak mentaati aturan hukum poligami bersifat subjektif, dengan kecenderungan mayoritas bersifat negatif karena tidak mentaati aturan. Mereka memilih melakukan poligami dengan perkawinan sirri. Perkawinan secara sirri menjadi politik identitas pilihan hidup karena berbagai pertimbangan baik pertimbangan yuridis maupun non yuridis. Kondisi ini berdampak pada dilema status hukum perkawinan poligami itu sendiri. Status perkawinan dianggap sah jika dilakukan secara resmi dan begitu juga sebaliknya, tidak dianggap sah jika dilakukan secara sirri. Perkawinan poligami ini juga berimbas pada status hukum suami, para istri dan anak-anaknya dalam keluarga.
\end{abstract}

\section{Kata Kunci:}

Budaya Hukum; Dampak Hukum; Perkawinan Poligami; Perkawinan Sirri

\section{Introduction}

Article 3 paragraph (1) of Indonesia Law Number 1 of 1975 concerning marriage (hereinafter referred to as Marriage Law) mentions that the principle of marriage law is monogamy. However, polygamy with strict conditions is allowed based on the provisions of Article 3 paragraph (2), either categorized as alternative in Article 4 or as cumulative in Article 5. These legal provisions are basically 
ambiguous $^{1}$ and therefore trigger legal uncertainty in its implementation. As a result, polygamy remains an issue that put people in dispute between pro and contra. ${ }^{2}$

Similar provisions also apply in Malaysia based on the Deed of Islamic Family Law (Allied Territories) of $1984^{3}$ with a slight difference from those in Indonesia. Malaysian law requires a judge's decision and permission from the previous wife to perform polygamy. However, a Sharia court decision could replace the consent of wife. ${ }^{4}$ Regulations on polygamy eventually lead to two groups; the pros and cons. Pros group relies their basic argument on the fact that Islam justifies polygamy as a part of Sunnah as well as an effort for avoiding immorality and empowering women. ${ }^{5}$ Among others, supporters of this group are Puspo Wardoyo with his Polygamy Award 6 and the Ikhwan Global Polygamy Club chaired by Muhammad

1 The term monogamy was not absolutely used by Hotnidah Nasution. See Hotnidah Nasution in Nur Choirin YD, Menyoal Ijin Poligami bagi Pegawai Negeri Sipil (Questioning Polygamy Permit for Civil Servants), Yin Yang Journal, STAIN Purwokerto Gender Study Center, Vol. 5 No.2 Jul-Dec 2010, 2010, 227-242. The term open monogamy was used by Hilman Hadikusuma, see Hilman Hadikusuma, Hukum Perkawinan Indonesia (Indonesian Marriage Law), Customary Law, Religious Law, $4^{\text {th }}$ edition, Mandar Maju, Bandung, 2011, 32. The term gray monogamy principle, meanwhile is used by another author. See in Shinta Dewi Rismawati, Persepsi Poligami di Mata Perempuan Kota Pekalongan (Perception of Polygamy in the Eyes of Women in Pekalongan City), Muwazah Journal published by the STAIN Gender Study Center, Pekalongan, Vol. 6 Number 2 December 2014 Edition, 146-154.

2The debate over the pros and cons of polygamy can be seen in Nurhayati's article, "Kontroversi Poligami (The Controversy of Polygamy)", Tempo, XXXV No. 42 (December 2006), 108; and Rumadi, "Momentum Reformasi Hukum Keluarga (Momentum for Family Law Reform)", Koran Tempo, (Jakarta). The Edition of Wednesday December 13, 2006, A10

3 Ibrahim, M., Muhammad, MSIBS, \& Samsudin, SIB (2018). Prosedur Poligami di Malaysia (Analisis Akta Undang-Undang Keluarga Islam Wilayah-Wilayah Persekutuan) (Procedure for Polygamy in Malaysia (Analysis of Deed of Law on Islamic Families in the Territorial Communities). Samarah: Journal of Family Law and Islamic Law, 2(1), 1-26.

4 Raihanah Haji Abdullah, Poligami di Malaysia (Polygamy in Malaysia), Sharia Journal, Number 2, 1999, 167

5 Puspo Wardoyo, Poligami: Kiat Sukses Beristri Banyak (Pengalaman Puspo Wardoyo Bersama 4 Istri (Polygamy: Successful Ways with Many Wives (Puspo Wardoyo's Experience with 4 Wives), Bumi Wacana, Solo, 2003, 14-15.

${ }^{6}$ Kompas, Poligami Award: Di Antara Dukungan dan Tantangan (Polygamy Award: Between Support and Challenges), 28 July 2003, http: // www. kompas.com/gayahidup/news. 
Umar Nur.7 Meanwhile, the representatives of cons group in Indonesia are Coalition of Indonesian Women (Kowani) and the Legal Aid Association of Indonesian Women for Justice (LBH). ${ }^{8}$ Their basic argument mentions that polygamy is gender-biased, possibly leading to violation of the human rights in the sense of domestic violence ${ }^{9}$ as well as greatly causing a divorce due to husband's injustice. ${ }^{10}$ Additionally, Romli exposed the reality of abundance of poverty, misery and destruction of families because of polygamy. ${ }^{11}$

Based on the explanations above, the phenomenon of polygamy is still interesting to study at least for two reasons. First, is the fact that although there are many success stories of polygamy and it is currently being heavily campaigned, rejection of it is still widespread. Second, although the normative rules are the same, it turns out to be diverse in practice between the obedient and disobedient ones.

The studies on polygamy in Pekalongan City had been conducted, including those of Rismawati which revealed the perception of women in viewing polygamy practices. 50 female respondents stated that 33 people (73\%) refused polygamy, but 12 people $(27 \%)$ agreed with polygamy. ${ }^{12}$ This result is different from the findings of Farah W. Mustafar which examined polygamy with female pilgrims of Global Ikwan. The pilgrims $100 \%$ agreed with polygamy on the grounds of God's destiny and the polygamy of "murshid". ${ }^{13}$ Meanwhile, Trigianto, in his

\footnotetext{
7 See Ratna Batara Munti, Demokrasi Keintiman Seksualitas di Era Global (Democracy of the Intimacy of Sexuality in the Global Era), LKis, Yogyakarta, 2005, 134-135.

8 Ratna Batara Munti, Ibid, 137

${ }_{9}$ Ratna Batara Munti, Ibid, 138.

10 Raihanah Haji Abdullah, Poligami di Malaysia (Polygamy in Malaysia), Sharia Journal, Number 2, 1999, 167-183

11 Dewani Romli, Poligami Prespektif Gender (Gender Perspective Polygamy), Al-Adyan Journal of Interfaith Studies, Vol. 5, No. 1 (2010), 105

12 Shinta Dewi Rismawati, " Persepsi Poligami di Mata Perempuan Kota Pekalongan (Perception of Polygamy in the Eyes of Women in Pekalongan City)," Muwazah was published by PSG STAIN Pekalongan, Vol. 6, No. 2, (December, 2014), 146-154.

13 Farah Wahida Mustafar dkk, Konsep Poligami Mengikut Perspektif Para Isteri dalam Jemaah Global Ikhwan Sdn. Bhd, Artikel Available July 2018. Farah Wahida Mustafar et al, Konsep Poligami Mengikut Perspektif Para Isteri dalam Jemaah Global Ikhwan (the Concept of Polygamy Following the Perspectives of Wives in the Global Congregation of the Ikhwan Sdn. Bhd), Article is Available in July 2018. www.Researchgate.Net./Publication/326225222_Konsep_Poligami_Mengikut_Presp ektif_Para_Istri_Dalam_Jemaah_Global_Ikhwan_Sdn_Bhd
} 
research on the dispensation of polygamy for religious court judges in 2013, showed that there were eight cases of polygamy permit applications examined by the Pekalongan Religious Court. Seven of them were granted because they met applicable legal requirements. ${ }^{14}$

Other than that, regarding power relations in polygamy marriage communication, Wibowo, another researcher, showed that power relations in polygamous family communication are dominated by husband. This can be seen from the number of residents in the Gama Permai Housing complex in the West Pekalongan District with five polygamous families. One of them was carried out officially, while four others were performed informally or in sirri. ${ }^{15}$

The novelty of this paper is the use of socio legal perspective with a relatively new analysis instrument on the legal culture and optional political identity in the implementation of polygamy. This has not been conducted in previous studies. In this paper, we furthermore argue that the legal culture of polygamists in their marriages is an important element that determines the optional political identity and their marital status. The phenomenon of the one's obedience or disobedience to any laws is largely determined by his/her legal culture. Relating to this, Hart stated that "actually, law cannot be separated from social pressure. Therefore, to understand law and existing legal system, the perspective of people as the objects of legal norms must be considered. This condition requires internal and external legal approach".16

Thus, understanding the reality of polygamy is not enough by only reading the legal text, but also based on the reality of law in a society. Meaning of law in a certain community becomes important because of the effectiveness of the law. It is not only because of its good and complete legal substance and modern legal structure, but precisely also because of its legal culture. ${ }^{17}$

14 Ali Trigiatno, Ijin Poligami Di Kota Pekalongan (Polygamy Permit in Pekalongan City). Research Journal. Vol 5 Number 1, 2013, 27-39

15 Brigitta Agni Wibowo, Relasi Kuasa dalam Komunikasi Keluarga Poligami (Power Relations in the Communication of Polygamy Families), (A Qualitative Analysis of Families with Polygamous Marriage Relations in Muslim Communities in Pekalongan City), downloaded from http://ejournal.uajy.ac.id/284/1/0KOM03630.pdf

16HLA Hart, The Concept of Law, Oxford University, Oxford, 1961, 86-87.

17 Faisal, Memahami Hukum Progresif (Understanding Progressive Law), Thafa Media, Yogyakarta, 2014, 23. 
The study of the legal culture and optional political identity of polygamy family is important because a reality of polygamy is no longer depicted in black and white. It invites readers to understand the legal reality in a natural way. Legal culture, meanwhile, is a person's attitude towards law and the legal system related to perceptions, beliefs, values, thoughts, and expectations. It strongly relates to an atmosphere of social thought and power that determine how law is used, avoided, or abused. Furthermore, it mutually depends on public legal awareness; the higher legal awareness of the community, the better the created legal culture will be. ${ }^{18}$

Based on the arguments above, this paper questions how the legal culture of polygamist in Pekalongan City is and how the optional political identity of the polygamists in carrying out polygamous marriages and the legal status of their marriages are.

\section{Research Method}

The type of the research used here was socio legal studies with a tradition of qualitative research that describes in detail the working of legal texts (regulations and policies) on polygamy when dealing with the context of the community of Pekalongan City. The sources of the research data used primary and secondary data sources. The primary data sources were obtained directly from the field through a series of indepth interviews with the informants and also observations. Then, the secondary data sources were in the form of primary legal materials consisting of legal regulations related to marriage from the general rules to the organic ones. The secondary and tertiary legal materials were from the books and library materials relevant to the investigated issue.

The number of key informants was six married polygamy couples, while supporting informants were the polygamists' family members (children and children in-laws), relatives and neighbors, the

\footnotetext{
18. Lawrence M. Friedman, The Legal System A Social Science Perspective, Russell Sage Foundation, New York, 1975, 15, 194 and 223. See also Satjipto Rahardjo, Sisi-Sisi Hukum di Indonesia (Legal Sides in Indonesia), Publisher, Kompas, Jakarta, 2003, 96. Compare Sulistyowati Irianto, Perempuan di Antara Berbagai Pilihan Hukum (Woman Among Various Legal Options), Indonesian Obor Foundation, Jakarta, 2003, 287. Also read Daniel S. Lev, Hukum Dan Politik Di Indonesia (Law and Politics in Indonesia), Institute for Economic and Social Research, Education and Information (LP3ES), Jakarta, 2000, 119.
} 
officials in the field of marriage such as the officers of the marriage registry office in the Religious Affair Office (KUA) and the Registrar of Religious Courts. The instruments used were in the form of the list of interview questions, check lists, stationery, tape recorders, cameras, field notes and others. To get information, the author involved observation and in-depth interviews. The involved observations were through observing the legal culture of the polygamists in carrying out their marriages, their daily lives and so on. Meanwhile, the interviews were conducted with the key informants and supporting informants who were selected in a purposive way according to the established criteria.

The criteria included the polygamy marriage families held for more than two years, having children from their marriages, and carrying out the marriage both officially and informally ( $\underline{\underline{s i r r}})$. Any data obtained from key informants will then be developed following the principle of snowball.

Next on, to obtain the secondary data, the author used literary studies while to check credibility of the whole information and data, we used triangulation techniques with data sources and methods. The data analysis techniques used the interactive model of Mattew B. Miles and A. Michael Huberman which operates in three cycles of activity; data presentation, data reduction and withdrawal, ${ }^{19}$ to make comprehensive and reflective analysis.

\section{Finding and Discussion}

\section{Polygamy Marriage: Negative Legal Culture}

Along with the rapid economic development of Pekalongan City known as the City of Santri, ${ }^{20}$ Batik City, ${ }^{21}$ and also the Creative

\footnotetext{
19 Mattew B Miles dan A Michael Huberman, An Expanded Soucers Book, Qualitive Data Analysis, Sage Publications, 1992

20 AM M Khafidz Ma'shum, Persepsi dan Perilaku Ulama Pesisir Terhadap Bank Syariah (Studi Terhadap Pembentukan Persepsi dan Perilaku Utama Terhadap Bank Syariah Di Pekalogan (Perception and Behavior of Coastal Ulama Towards Islamic Banks (A Study of the Establishment of Perceptions and Main Behaviors of Islamic Banks in Pekalogan)), Dissertation, UIN Sunan Kalijaga, Yogyakarta, 2017, 11

21 Rita Rahmawati, Teologi Buruh : Agama dan Sikap Pasrah Perempuan Buruh Sanggan Batik (Labor Theology: Religion and the Submissive Attitude of Sanggan Batik Workers), Research Journal, Vol. 11, No. 2, November 2014, P3M STAIN Pekalongan, 212-213. See also Triana Sofiani, Perilaku Curang dalam Transaksi Bisnis Batik Di Kota Pekalongan (Cheating Behavior in Batik Business Transactions in Pekalongan City), The 3rd University
} 
City of the World, the facts showed that polygamy in this region belongs to unsegmented people. It was not only among upper-middle class society (employers, teachers/lecturers, Civil Servants (PNS), Police/Indonesian National Armed Forces (TNI)), but also the lower economic class (pedicab drivers and garbage collectors).

However, it must be admitted that the number of polygamy in Pekalongan was not recorded clearly, although the Secretary of Pekalongan Religious Court stated that at least, at each of the last five years, five couples applied for the polygamy permission. Generally, they consisted of businessmen or civil servants. ${ }^{22}$ Therefore, there is approximately 25 polygamy permit application in the past five years.

The data above shows that polygamy really exists and occurs in Pekalongan. Some of them are official and some others are through sirri mechanism. The author assumed that the actual number of polygamy was much higher than what was recorded, because mostly, polygamy are in sirri and unofficial ones. Moreover, Setiawati said about a high correlation between sirri and polygamous marriages. ${ }^{23}$ This means that the higher number of the unofficial marriages are performed, the higher possibility of the polygamy family would be.

In the context of polygamy in Pekalongan City, the following data illustrates the profile of the perpetrators, mode, legal culture and status of polygamists' children:

Table 1:

Profile of Polygamy Couples, Marriage Type, Mode and Status of Children ${ }^{24}$

\begin{tabular}{|c|c|c|c|c|}
\hline $\begin{array}{c}\text { Husband/age/ } \\
\text { occupation/ } \\
\text { education }\end{array}$ & $\begin{array}{c}\text { Wife I/age/ } \\
\text { occupation/ } \\
\text { education }\end{array}$ & $\begin{array}{c}\text { Wife II/age/ } \\
\text { occupation/ } \\
\text { education/ } \\
\text { status when }\end{array}$ & $\begin{array}{c}\text { Type of } \\
\text { marriage/ } \\
\text { mode, reasons } \\
\text { for }\end{array}$ & $\begin{array}{c}\text { Child } \\
\text { Status }\end{array}$ \\
\hline
\end{tabular}

Research Colloquium, 2016, ISSN 2407-9189, UMS, 2016, 197. Shinta Dewi Rismawati, Ibid., 255.

22. Interview with the Religious Court Secretary of Pekalongan City in his office on February 12, 2018.

${ }^{23}$ Effi Setiawati, Pengalaman Perempuan dalam Menjalani Kehidupan Perkawinan Nikah Siri, Studi Kasus di Kecamatan Sumbersari Kabupaten Jember Jawa Timur (Women's Experience in Living the Life of Siri Marriage), Case Study in Sumbersari District, Jember Regency East Java,, in Women's Journal, Considering Polygamy, No. 31, 2003, 40

${ }^{24}$ This data is the data that had been processed and analyzed by the author. 


\begin{tabular}{|c|c|c|c|c|}
\hline & & married & justification & \\
\hline $\begin{array}{l}\text { MA/37/ } \\
\text { private- } \\
\text { delivery } \\
\text { business / } \\
\text { High School }\end{array}$ & $\begin{array}{l}\mathrm{SN} / 41 / \\
\text { Civil } \\
\text { servant- } \\
\text { nurse/D.3/ } \\
3 \text { children }\end{array}$ & $\begin{array}{l}\text { RP/19/ } \\
\text { housewife/ } \\
\text { Junior High } \\
\text { School/ } \\
1 \text { child/ } \\
\text { daughter }\end{array}$ & $\begin{array}{l}\underline{\text { Sirri- }} \\
\text { unrecorded, } \\
\text { no wife I's } \\
\text { permit, doing } \\
\text { sunna, forcing } \\
\text { her to accept } \\
\text { and } \\
\text { threatening } \\
\text { her for divorce } \\
\text { and biological } \\
\text { needs, family } \\
\text { economic } \\
\text { fulfilment, and } \\
\text { for the sake of } \\
\text { family good } \\
\text { name and } \\
\text { children }\end{array}$ & $\begin{array}{l}\text { Not } \\
\text { recorded in } \\
\text { the family } \\
\text { card, only } \\
\text { name of } \\
\text { mother } \\
\text { mentioned } \\
\text { in birth } \\
\text { certificate }\end{array}$ \\
\hline $\begin{array}{l}\mathrm{H} . \mathrm{Mz} / 41 / \\
\text { private-batik } \\
\text { business/ } \\
\text { bachelor }\end{array}$ & $\begin{array}{l}\text { Hj Is/39/ } \\
\text { housewife/ } \\
\text { bachelor/4 } \\
\text { children }\end{array}$ & $\begin{array}{l}\mathrm{Hj} \mathrm{Az/30/} \\
\text { housewife/ } \\
\text { High } \\
\text { School/ } \\
2 \text { child/ } \\
\text { daughters }\end{array}$ & $\begin{array}{l}\text { Officially- } \\
\text { recorded, } \\
\text { doing sunna, } \\
\text { Wife I's } \\
\text { permission- } \\
\text { and support, II } \\
\text { wife's social } \\
\text { status, hoping } \\
\text { for the } \\
\text { blessing of } \\
\text { husband and } \\
\text { Allah, and } \\
\text { enough } \\
\text { fulfullment of } \\
\text { physical and } \\
\text { spiritual } \\
\text { needs. }\end{array}$ & $\begin{array}{l}\text { Recorded } \\
\text { in the } \\
\text { family } \\
\text { card, with } \\
\text { the name of } \\
\text { mother and } \\
\text { father } \\
\text { mentioned } \\
\text { in birth } \\
\text { certificate }\end{array}$ \\
\hline $\begin{array}{l}\mathrm{H} / 65 / \\
\text { retired Civil } \\
\text { servant/ } \\
\text { Diploma }\end{array}$ & $\begin{array}{l}\mathrm{T} / 59 / \\
\text { private } \\
\text { teacher/4 } \\
\text { children/ } \\
6 \\
\text { grandchildr }\end{array}$ & $\begin{array}{l}\text { M/40/house } \\
\text { wife/ Junior } \\
\text { High / } \\
3 \text { children } \\
\text { (1 from } \\
\text { previous }\end{array}$ & $\begin{array}{l}\text { Sirri- } \\
\text { unrecorded/d } \\
\text { oing sunna, no } \\
\text { wife I's } \\
\text { permission, } \\
\text { forcing the }\end{array}$ & $\begin{array}{l}\text { Not } \\
\text { recorded in } \\
\text { the family } \\
\text { card, only } \\
\text { name of } \\
\text { mother }\end{array}$ \\
\hline
\end{tabular}




\begin{tabular}{|c|c|c|c|c|}
\hline & en & $\begin{array}{l}\text { marriage)/ } \\
\text { widow }\end{array}$ & $\begin{array}{l}\text { wife I, } \\
\text { pregnant } \\
\text { condition, } \\
\text { biological } \\
\text { needs of } \\
\text { husband, } \\
\text { economic } \\
\text { fulfillment and } \\
\text { social status } \\
\text { for children } \\
\text { and wife II. }\end{array}$ & $\begin{array}{l}\text { found in } \\
\text { birth } \\
\text { certificate }\end{array}$ \\
\hline $\begin{array}{l}\mathrm{R} / 47 / \\
\text { private -café } \\
\text { business/ } \\
\text { Bachelor }\end{array}$ & $\begin{array}{l}\text { Mh/45/ } \\
\text { housewife/ } \\
\text { bachelor/3 } \\
\text { children }\end{array}$ & $\begin{array}{l}\text { As/26/ } \\
\text { housewife/ } \\
\text { High } \\
\text { School/2 } \\
\text { chidren } \\
\text { (1 from } \\
\text { previous } \\
\text { marriage)/ } \\
\text { widow }\end{array}$ & $\begin{array}{l}\text { Sirri- } \\
\text { unrecorded/D } \\
\text { oing sunnah, } \\
\text { No wife I and } \\
\text { family's } \\
\text { permission, } \\
\text { forcing and } \\
\text { threatening for } \\
\text { divorce, } \\
\text { willingness to } \\
\text { have a a son, } \\
\text { for a social } \\
\text { status as a rich } \\
\text { man, } \\
\text { husband's } \\
\text { biological } \\
\text { needs, } \\
\text { economic } \\
\text { fulfillment, } \\
\text { family's good } \\
\text { names, scared } \\
\text { with the } \\
\text { stigma of } \\
\text { widow and for } \\
\text { the sake of } \\
\text { children's } \\
\text { future }\end{array}$ & $\begin{array}{l}\text { Not } \\
\text { recorded in } \\
\text { the family } \\
\text { card, only } \\
\text { name of } \\
\text { mother } \\
\text { found in } \\
\text { birth } \\
\text { certificate }\end{array}$ \\
\hline $\begin{array}{l}\text { MK/50/ } \\
\text { Civil } \\
\text { Servant/ }\end{array}$ & $\begin{array}{l}\text { I/49/ } \\
\text { housewife } \\
\text { / bachelor }\end{array}$ & $\begin{array}{l}\text { N/43/ } \\
\text { Teacher-Civil } \\
\text { Servant/ }\end{array}$ & $\begin{array}{l}\text { Sirri- } \\
\text { unrecorded- } \\
\text { doing sunnah, }\end{array}$ & $\begin{array}{l}\text { Not } \\
\text { recorded in } \\
\text { the family }\end{array}$ \\
\hline
\end{tabular}




\begin{tabular}{|c|c|c|c|c|}
\hline $\begin{array}{l}\text { Master } \\
\text { degree }\end{array}$ & /3 chidren & $\begin{array}{l}\text { bachelor / } \\
3 \text { chidren (2 } \\
\text { from } \\
\text { previous } \\
\text { marriage)/ } \\
\text { widow }\end{array}$ & $\begin{array}{l}\text { first wife } \\
\text { permitted but } \\
\text { the boss did } \\
\text { not, the second } \\
\text { wife is a civil } \\
\text { servant so } \\
\text { dealing with } \\
\text { complicated } \\
\text { bureaucracy, } \\
\text { the reason of } \\
\text { love, economic } \\
\text { need } \\
\text { fulfillment and } \\
\text { keeping family } \\
\text { good name, } \\
\text { fear of widow } \\
\text { stigma and for } \\
\text { children's } \\
\text { future. }\end{array}$ & $\begin{array}{l}\text { card, only } \\
\text { name of } \\
\text { mother } \\
\text { found in } \\
\text { birth } \\
\text { certificate }\end{array}$ \\
\hline $\begin{array}{l}\text { Jh/62/ } \\
\text { worker- } \\
\text { garbage } \\
\text { collector/ } \\
\text { Junior High } \\
\text { School }\end{array}$ & $\begin{array}{l}\text { Am/57/ } \\
\text { housewife/ } \\
\text { Elementary } \\
\text { School / } \\
4 \text { children }\end{array}$ & $\begin{array}{l}\text { H/37/ } \\
\text { housewife/ } \\
\text { Elementary } \\
\text { School/3 } \\
\text { chidren } \\
\text { (2 from } \\
\text { previous } \\
\text { marriage)/ } \\
\text { widow }\end{array}$ & $\begin{array}{l}\text { Sirri- } \\
\text { unrecorded- } \\
\text { doing Sunnah, } \\
\text { carrying out } \\
\text { secret affair } \\
\text { and husband's } \\
\text { biological } \\
\text { needs, } \\
\text { economic need } \\
\text { fulfillment and } \\
\text { keeping family } \\
\text { good name, } \\
\text { fear of widow } \\
\text { stigma and for } \\
\text { children's } \\
\text { future }\end{array}$ & $\begin{array}{l}\text { Not } \\
\text { recorded in } \\
\text { family } \\
\text { card, only } \\
\text { name of } \\
\text { mather in } \\
\text { birth } \\
\text { certificate }\end{array}$ \\
\hline
\end{tabular}

The above data shows that the polygamists in Pekalongan were quite diverse from the age, occupation, education, the second wife's status, number of children, mode, reasons or justification, as well as marital and child status. In terms of age, the husbands who performed polygamy range from 37 to 65 years old, and the first 
wives range from 39 to 59 years old. Then, the ages of the young wife are between 19 and 43 years old. In general, the data also shows that the age of polygamists (both husband and wife) at the time of their marriage is classified as productive age. For the husbands, 40 years or older is the age of both economically and socially independent. This is in line with the opinion of Katkovsky W and Garlow stating that independence is a person's capacity to manage their own lives. Thus, the individual can determine and decide what he/she wants and can be responsible for the decisions, 25 including for doing polygamy.

The uncertainty on polygamy numbers among Pekalongan residents, basically, was strongly influenced by both non-legal and legal factors as well. The table 1 above clearly shows reasons and or justification of non-legal polygamy which varied from religious, economic, social, biological to psychological reasons. On the husband's side, the reason is mostly on religious tendency for implementing sunnah, avoiding adultery, fulfilling biological need, and confirming social status as rich men. Meanwhile, non-legal factors in wife's side are mostly about economic fulfillment, the escape from stigma status as widows, keeping the good name of the family, maintaing the future of children, fulfillment of biological needs and implementing sunnah as well. In Pekalongan, according to the data, only two women (H. Mz's wives) who said that getting married in a polygamy family is merely for the sake of God's blessing. In fact, the awareness of $\mathrm{H}$, Mz's wives was inseparable from their intense interaction in al-Syafi'iyah recitation community. The wives did not refuse to be neither first nor second wife. This phenomenon is quite similar to the concept of women who follow the Ihwan Global Congregation on polygamy. ${ }^{26}$

Meanwhile, the legal factors are mainly on the normative rules of polygamy when the actors interpreted and obeyed or disobeyed the law. In this context, the legal culture of the actor in interpreting as well as either obeying or disobeying polygamy ultimately reflected whether their standing are positive or negative. A person's legal culture was strongly influenced by his/her interpretation on the normative values of any regulation. Relating to this, Supardi Mursalin mentioned that legal culture is very likely influenced by people's

\footnotetext{
${ }^{25}$ Katkovsky.W. \& Garlow, L., The Psychology of Adjustment and Competence, Winthrop Publishers Inc, USA. 1986, 54

26 Farah Wahida Mustafar et al, Ibid.
} 
understanding on the Marriage Law and violations of the procedure that cause marriage cancellation by the judge. ${ }^{27}$ In this context, the informant's understanding and ability to implement the legal provisions regarding polygamy becomes another important point.

The author argues that according to Indonesian Marriage Law, there are two requirements for polygamy, which are material and formal. Material requirements refer to essential requirements for polygamy to carry out. These conditions include the willingness of related parties, including the wives (Article 3 paragraph 2), the reasons allowing husbands to perform polygamy, mainly about the "dysfunction" of wife (Article 4 paragraph 2), the agreement of wives, a guarantee on husband's ability to fulfill the needs of wives and their children and the husbands' commitment of justice towards their wives and children (Article 5).28 Meanwhile, formal requirements refer to those related to procedural and administrative materials to gain legitimacy from the state, including the issuance of polygamy permit (Article $56 \mathrm{KHI}$ ) and the settlement of application fee.

The formal requirements are a continuation after the fulfillment of material requirements, as they only relate to procedure and legality of polygamy. Between the two types of conditions, the material normative ones is the hardest requirement to fulfill, according to five out of six husbands (respondents). Consequently, sirri polygamy became their choice. Relating to the sirri marriage, Ramulyo defined it as a marriage of Muslims by fulfilling the pillars and conditions of marriage without formal registration of the marriage law. ${ }^{29}$

\footnotetext{
27 Supardi Mursalin, Menolak Poligami: Studi Tentang UU Perkawinan dan Hukum Islam (Refusing Polygamy: A Study of Marriage Law and Islamic Law), Pustaka Pelajar, Yogyakarta, 2007, v.

28 Shinta Dewi Rismawati, Konstruksi Hukum Poligami di Indonesia (Prespektif Hukum Feminis) (Construction of Polygamy Law in Indonesia (Feminist Legal Perspective)), Journal, Vol. 9, No. 2. 2017, 125-137

${ }^{29}$ M. Idris Ramulyo, Suatu Perbandingan Antara Ajara Syafii dan Wasiat Wajib Di Mesir Tentang Pembagian Harta Warisan Menurut Islam, Majalah Hukum dan Pembangunan, Nomor 2 Tahun XII, 2000, 23. M. Idris Ramulyo, Suatu Perbandingan Antara Ajara Syafii dan Wasiat Wajib Di Mesir Tentang Pembagian Harta Warisan Menurut Islam (A Comparison Between Shafi'i Teachings and Mandatory Wills in Egypt Regarding Distribution of Inheritance According to Islam), Law and Development Magazine, Number 2 Year XII, 2000, 23.
} 
The strict rule of polygamy marriage leads people to exploit the legal loopholes and make it an excuse to carry out polygamy without following the law. People, therefore, tend to build a polygamous family by doing sirri and unregistered marriage. Likewise, a fact of difficulty in getting a wife's permission (oral or written) and the absence of sanctions for husbands who break the law make them easy to carry out any legal violations even criminal offenses. In this extent, Reynata enlisted some modes that a husband likes to use in doing polygamy. They consist of getting sirri marriage, faking the identity data, geting marriadge without a wife's permission and forcing her to give permission. ${ }^{30}$

In the context of Pekalongan, the husbands' mode of polygamy marriage were getting marriage without the permission of wives (3 cases), forcing the wives to give permission (3 cases), engaging in a secretful marriage (which the first wife doesn't know about) and getting sirri marriadge (5 cases). This makes it clear that the majority of polygamists' legal culture was negative as they ignored the legal provisions regarding polygamy, particularly because of difficulties in obtaining permission from the wives. The absence of wife's permission then impacts the same of the judge's stand in the religious court. It is also obvious that the negative legal culture is in line with low level of legal awareness among polygamy couples as well as the complicated procedure of polygamy marriage. As a consequence, this condition justifies the argument of Friedman ${ }^{31}$ on the correlation between legal culture and legal awareness.

Regarding with the process of fulfilling the requirement, the authors believe that the degree of difficulty on legal provision fulfillment is subjective or depending on intention of each individual. A husband who unseriously intends to obey the rule will tend to think that the legal terms and procedures for polygamy are very difficult to fulfill and therefore sirri polygamy becaomes an alternative and vice versa. Irresponsibility or disobedience on the rule is clear from the type of marriage choices whether it is official or not. The majority of husbands said that for practical reasons, a marriage is sufficient to do through sirri procedure. The important thing to consider is the

30 See Vony Reyneta, Kebijakan Poligami : Kekerasan Negara Terhadap Perempuan (Polygamy Policy: State Violence Against Women), Women's Journal, Considering Polygamy, Vol. 31, 2003, 10

${ }^{31}$ Lawrence W. Friedman, Ibid. 
lawfulness of marriage based on religious teaching ( $\underline{h} a l \bar{l} l)$. This condition makes the law on polygamy ineffective because of low level of awareness and understanding of the actors. The almost same thing occurs in Madura where polygamy is typically through individual or sirri procedure and carried out without the consent even detection of the first wife. ${ }^{32}$

The diversity on either obeying or disobeying the rules of marriage law causes a variety of legal cultures on polygamy. In this talk, Rahardjo said that the legal culture of a nation or a person is determined by certain values serving as references in applying the law. ${ }^{33}$ Meanwhile, Irianto mentioned that legal culture is a part of the social forces existing in a society which sustainably influence the operation of legal system on whether it is obeyed or disobeyed. ${ }^{34}$ Furthermore, Friedman thought that the legal culture consists of ideas, values, attitudes and beliefs of a person to hold on in dealing with any legal system. He continued that the legal system can simply be described as a ship on the sea that sails with social force. ${ }^{35}$ Therefore, legal awareness is a mental condition of a subject when he/ she has to face a normative command in determining the choice of two-dimensional complete behavior, namely cognitive and affective dimension, regarding the law that he/she literally knows that it demands obedience. ${ }^{36}$ Here, the authors believe that legal culture is a driving force that potentially encourages the operation of any legal system. As a driving force, the legal culture based on the values of meaning, perception, expectations, attitudes and behavior becomes the key that determines the effectiveness of any legal system.

\footnotetext{
32 Abd. Warits and Abd. Wahed, Praktik Poligami Di Bawah Tangan di Desa Laden Kabupaten Pamekasan (The Practice of Individual Polygamy in Laden Village, Pamekasan Regency), Al Ihkam Journal of Law and Social Institutions, Vol 9. No 2. 2014, 223-259

33 Satjipto Rahardjo, Sisi-Sisi Hukum di Indonesia (Legal Sides in Indonesia), Publisher, Kompas, Jakarta, 2003, 96.

34 Sulistyowati Irianto, Perempuan di antara Berbagai Pilihan Hukum (Woman among Various Legal Options), Yayasan Obor Indonesia, Jakarta, 2003, 287.

35 See Lawrence M. Friedman, Legal Culture and the Welfare State, in Stewart Macaulay, Lawrence M. Friedman and John Stookey, Law and Society Reading on the Social Study of Law, WW Norton and Company, New York London, 1995, 269.

36 Soetandyo Wignosoebroto, Hukum, Paradigma dan Dinamika Masalahnya (Law, Paradigm and Problem Dynamics), 2002, Elsam, Jakarta, 373.
} 
The data in table 1 above shows that the legal culture of the polygamists is quite diverse each others. Some of respondents obey and fulfill the provisions of polygamy as regulated in Marriage Law and other organic legal rules. One of them was $\mathrm{H} \mathrm{Mz}$ who legally got married to his second wife considering the consent of the first wife, religious teaching as well as the nation law. Furthermore, he became surer to carry it out as he believed that he himself would be fair as suggested in religious teachings. For $\mathrm{H} \mathrm{Mz}$ who worked as a businessman, the legal provisions he adhered to were Law No. 1 of 1974 concerning Marriage, PP No. 9 of 1975 and KHI (Kompilasi Hukum Islam or Islamic Law Compilation). In other word, H Mz's legal culture was positive. Meanwhile, the reason for his second marriage was mostly because of his encouragement to achieve the blessing of Allah SWT. In the other hand, his motivation to register his second marriage was to provide the legal protection on his marriage legal status and as well his wife and children. $\mathrm{H} \mathrm{Mz}$ considered that the action was a fair act and as a representation of husband's responsiblity.

Meanwhile, the negative legal culture in polygamy marriage was shown by MA, H, R, Mk and Jn who did neither attend to nor obey the provisions of polygamy law for various reasons then chose to take sirri procedure. The main reasons for that choice were rational and pragmatic thinking; they did not want to get bothered because the conditions were complicated and difficult to fulfill. In addition, a polygamous husband was motivated by the following reasons: meeting biological needs, safeguarding the good name of his wife, the status of second wife as a civil servant $(\mathrm{N})$ who, according to the law, is prohibited to be a second wife, not getting consent from the first wife, not hurting the first wife's feelings and her family, avoiding any Court complicated procedure, getting offspring, not committing immorality (adultery) anymore, and the lawfulness of polygamy according to religious teaching and state law.

The conclusion of this talk is that the legal culture of polygamists in Pekalongan City tends to be negative because of husbands' subjectivity in fulfilling the legal requirements and procedures for conducting polygamy. They claimed to have experienced the complexity and difficulty of meeting applicable regulations. This condition caused them to prefer polygamy marriage 
in sirri with pragmatic and rational reasons according to their own consideration.

\section{Polygamous Marriage: Identity Politic of Rational Choice}

Table 1 above shows a variety of husbands' occupation. Most of them work in private sector or become entrepreneurs (MA, H. Mz and $\mathrm{R})$, followed by civil servants ( $\mathrm{H}$ and $\mathrm{Mk}$ ) and laborers (Jh). On the other hand, the first wives are mostly housewives $(\mathrm{Hj}$. Is, Mh, I and Am) followed by civil servants (SN) and private teachers (T). Likewise, occupation of the second wives were also dominated by housewives (Rp. Hj. Az, M, As and H) and PNS teachers (N). A husband who works as a private worker, businessman or civil servant with the working period about $15-20$ years tend to be economically established and this economic efficacy may drive them to either formal or informal polygamy. This economic independence is then supported by a developing culture or belief in society; the value of a husband's success is clear from his economic life and the number of his wives. An informant said that the willingness to get social recognition as a rich man and the polygamy of the Prophet encouraged him for polygamy. ${ }^{37}$

The economic condition of husband is generally very different from those of wives, both first and second. There were indeed a few wives who work as civil servants, but most of them are housewife. Becoming a housewife makes them very dependent on their husbands as the main breadwinner of family. They become marginalized in economic sector and it leads them to very low access to family assets. $^{38}$ As a consequence, they did not have a strong bargaining power in family decision making and free access to family financial management. Furthermore, they are also unable to refuse their husbands' polygamous marriage. Relating to this, Dickson said that there found several reasons on why a wife accepts her husband's polygamous marriage, i.e: (a) to control their own desire, (b) to share responsibilities in household management with another wife, (c) to be more independent and not dependent on her husband, (d) to have a

\footnotetext{
37 Interview with H. Mz, R and MA in their homes in July 2016

38 Eva Kusuma Sundari, Perempuan Menguggat (Claiming Woman), Lappera Pustaka Utama, Yogyakarta, 2004, 9
} 
stronger dependency on the husband, and (e) because of fear from getting socially negative stigma. ${ }^{39}$

Sharing the same opinion with Dikson, Nurmila said that the economic dependence experienced by women on men is the cause of polygamous marriages. This pattern of dependency even often triggers family violence. ${ }^{40}$ Meanwhile, Kinasih mentioned that generally, when women become widows, they tend to deal with the problem of economic hardship to support themselves and their children life. As long as they become widows, they tend to feel anxious because people will focus on every detail of them. ${ }^{41}$ The authors agree with the opinion of Dickson and Nurmila that in terms of wife, economic factors and fear of stigma of widow status are the main reasons why they are willing to be both first and second wives. Therefore, in the context of Pekalongan, economic dependency and fear of being socially stigmatized as widows force the first wives to survive in the marriage as well as compel the second wives to get married to other woman's husband. ${ }^{42}$ This is so advantagoeus for a husband because they will automatically have a strong bargaining power to control his wives and family. They will also be certainly dare to choose polygamy although common people still consider it as an extra-ordinary family.

In this era of globalization, the discussion of polygamy emerges in the midst of various forms of resistance to traditional family discourses. They range from a choice to be single, non-marital living together, single parents, infidelity, sexual freedom movements for Lesbians, Gay, Bisexuals and Transgender ( LGBT) as well as gender equality. The typology of this nowadays social movement is different from that in the past which emphasized women emancipation. Advances in information technology development have accelerated the spread of information on how to shape personal identity politics together with the strengthening discourse of international human

39 C. Dickson, Marriage and Family Problems, West Publishing Company, Metropolis, 2007,34 .

40 Nina Nurmila, Women, Islam and Everyday Life: Renegotiating Polygamy in Indonesia, Routledge, Taylor and Francis Group, London and New York, 2009, 117-130.

41 Sri Endah Kinasih, Perkawinan Kontrak di Masyarakat Kalisat (Contract Marriage in the Kalisat Community), Jurnal Perempuan No. 29, May 2003, 134

42 Read Rita Serena Kolibonso, Diskriminasi itu Bernama Kekerasaan Terhadap Perempuan (Discrimination Named Violence Against Women), Journal of Women 45, No. 45, 2006, 19. 
rights. ${ }^{43}$ In contrast to Cohen and Kennedy, Mc. Micheal said that in the era of globalization, the discourse of polygamy as a political choice of identity does not only belong to religious fundamentalists, but also a group who wants to express their return to the ease and security of traditional rules of behavior including maintaining pathriarcy as traditional family values. ${ }^{4}$

The group wants to restore the dominant power of men (husband) in controlling his wife and family under his arm. This is in line with what Anthony Giddens's statament that the independence (domination) of a person to choose polygamy is a part of social movement for identity politics called as politics of life choices or political struggles of alternative life choices ${ }^{45}$ which are different from the existing ones. Giddens and Beck further asserted that the growth of social actors who are empowered or able to exercise his/her electivity in everyday life is an important component in a global culture as they tend to be relatively self-aware and knowledgeable. They seek to shape their own lives by redefining the world around them. Reflexivity refers to the qualities of self-awareness, self-knowledge and contemplation. It is the capacity that individuals have to depend on themselves critically. ${ }^{46}$ Self-construction as a reflective project, meanwhile, is elemental part of the reflection of modernity in which an individual must find his/her own identity among a number of strategies and choices provided by abstract systems. ${ }^{47}$

In this context, the polygamous husbands mean those who have self-awareness about their position in a very dominant family relationship, self-knowledge about the requirements, polygamy procedures, as well as the economic and social conditions around them. The contemplation means that the husbands have thought carefully about the risks of polygamy. These considerations include

43 Robin Cohen dan Paul Kennedy, Global Sociology, Maxmillan Press Ltd, London, 2000, 290.

44 Philip Mc. Michael, Development and Social Change: A Global Prespective, Pine Forge Press, California, 2000, 242.

${ }^{45}$ Anthony Giddens, Runway World: How Globalization is Changing Our Lives, Gramedia Pustaka Utama, Jakarta, 2001, 49

46 Robin Cohen and Paul Kennedy, ibid., 36

47 Anthony Giddens, The Consequences of Modernity, Poilty Press Ltd, Cambridge, 2004, 112 
the motivation of polygamy, the economic (financial) conditions, the surrounding social life, the opportunities, and the risks that probably come in a polygamy family. The integration among three elements (self-awareness, self-knowledge and contemplation) finally encouraged them to be brave for having a different political identity from common husbands who are only monogamous.

The consideration process that integrates self-awareness, selfknowledge and contemplation with the opposite condition was also experienced by the wives both the first and second. The first ones made the decision (though initially forced) to accept their husbands' polygamy as a part of her obedience and a form of wife service. They realized that they could not afford their selves and their children economic needs when they had no income. They were also aware that over time, their ability to serve biological needs of their husbands will be limited. Meanwhile, the decision of the second wives to become a wife of a married man was based on the willingness to loose the status of a widow while they hoping that by becoming a second wife, there will be sufficient fulfillment needs for them and their children, including biological, social and psychological ones. From the facts above, it is clear that both husbands and wives of polygamy chose different identity politics from other common families because of their respective rationality and pragmatic considerations.

Into this extent, the authors agree with Mc. Michael related to the statement that polygamy is actually a discourse to restore patriarchal values. ${ }^{48}$ This is evident from the mode and excuse for justifying a husband to choose polygamy in order to strengthen his dominant position in the relationship among the husband over his wife(s), children, and family. The husbands might use coercion, threat to divorce their first wife, pregnancy of the next second wife, fulfilling biological needs, and the absence of a son. Therefore, the first wife was in difficult position for either getting divorced or being a co-wife. With those two difficult choices, the first wives finally chose to be a co-wife by letting of their husbands' polygamy. The first wives chose their identity politics as the first wives or old ones, while the husbands chose their identity politics as the husbands of two wives (old and young wives) and heads of households from two families at once.

48 Philip Mc. Michael, ibid., 242. 
Related to Giddens' opinion, the authors also believe that polygamy is an optional identity politics that drives a person to be the center of attention because his lifestyle and life choice are different from those of general public. Gidden referred this phenomenon as patetic narcissism, ${ }^{49}$ namely an orientation to self-satisfaction. Interestingly, it is not only a form of narcissistic defense against the threat from outside world due to individual's lack of control over it, but also a form of positive self adjustment into various kinds of global situations which influence everyday life $\mathrm{e}^{50}$ including, in this case, polygamy. In reality, the life pattern of a polygamous husband, of course, is different from the lifestyle of other husbands because he is required to share in many ways with his wives, children and family both in terms of quantity and quality.

A husband's choice for polygamy also leads to double risks, namely being praised and cursed at the same time. A polygamous husband is often praised as a man who is not afraid of his wife, an established and wealthy husband, a pious husband for following the sunnah Rasul and so on. On the other hand, he also got some negative stigmas, such as a selfish husband, a john, a husband of lust, a heart breaker, a violence actor in the household and so forth. The same occurs to the wives yet in different conditions and stigma, especially for the second wives who were considered as household destroyers or usurpers. This negative stigma has nothing to do with husband or wife's educational background whether they were highly or low educated. Moreover, based on husband's educational background, the respondents of this research were also diverse. There was one with master degrees (Mk), two ( $\mathrm{H}$. Mz and $\mathrm{R})$ with bachelor background, one $(\mathrm{H})$ with college degree, one (MA) who graduated from Senior High School (SLTA) and another (Jn) as Junior High School graduate. On the other hand, on the wife's side, one person (SN) graduated from College (D3), three ( $\mathrm{Hj}$. Is, $\mathrm{T}$ and I) as bachelor graduates, other three (Hj. Az, M and As) who graduated high school, and the last three (RP, Am and $\mathrm{H}$ ) who graduated junior high school.

The authors assumed that husband's educational background which was dominantly secondary and higher educations, they

\footnotetext{
49 Anthony Giddens, Ibid., 162.

50 Ibid., 163.
} 
typically knew about the legal requirements and procedures for polygamy and the necessity for recording their polygamous marriages in an authorized institution to make it legal. However, in reality, even though they knew the requirements and procedures for polygamy, they preferred marriage in sirri. This condition caused uncertainty in the number of polygamous marriages.

\section{Legal Status Dilema in Polygamy}

Marriage, as said by Suhanah, has sacred values because it is highly suggested in religious teachings. ${ }^{51}$ Therefore, it can relate, the state regulates the marriage. Additionally, Scholten mentioned that marriage is a legal relationship between a man and a woman to live together eternally and is recognized by the state. Scholten continued that as an eternal relationship, marriage must last last forever in a lifetime be endorsed by the state. Therefor, for him, every marriage couple needs to obey any regulations set by the state. 52 This is mainly because marriage is basically not merely a private domain between individuals. Instead, it is a public domain so that it requires state intervention and as a consequence, every country has a rule or law regarding marriage.

In relation to this, Erna Karim assumed that marriage is a process that involves emotional, economic, social aspects and official recognition by the community through applicable law. ${ }^{53}$ Meanwhile, according to Pamuji, is a public event with special social impact and affects other aspects of life such as economic, legal and even individual security aspects. With a multi-aspect impact, it is appropriate for the state to formulate policies in the field of marriage law, ${ }^{54}$ such as the registration. Marriage registration actually has a

51 Suhanah and Fauziah, Marriage Contract in Bogor Peak Area, Multicultural and Multireligious Journal, Vol x, No. 4, Research and Development Center for Religious Life Research and Development Agency of the Indonesian Ministry of Religion, Jakarta, 2011, 889.

52 Scholten, quoted from Prawirohamidjojo and Safioedin in the book FX Suhardana, Civil Law I, PT.Prenhallindo, Jakarta, 2001, 88.

53 Erna Karim, Divorce Approach in the Perspective of Sociology, writing in The Book on the Sociology of Family Sociology, Editor of TO Irhomi, Indonesian Torch Institute, Jakarta, 2004, 135.

54 Erna Karim, Ibid., 142. 
tremendous impact because it determines the status of recognition of the marriage by the state 55

In the context of Indonesia, marriage is considered legal when it meets the requirements such as the presence of prospective husband, prospective wife, marriage guardian, two witnesses and the consent granted.56 Furthermore, Article 2 paragraph (2) of the Marriage Law says so: "Every marriage is recorded according to the applicable laws and regulations". It means that marriage is considered legal by the state only when it is registered by an official from the authorized institution, namely the marriage registrar in the religious affairs office (KUA; Kantor Urusan Agama in Indonesia) and the civil registry office. As a consequence, marriage settlement needs to take place in front of officers to get legal consideration as well as legal force. In relation to marriage registration, Amin mentioned the purposes of it namely; first, to provide marital status as legally valid both on religious and state laws. Second, to ensure the fulfillment of the needs as well as the rights of wife and children. Third, to be a basic right for a wife to sue her husband in any unexpected condition. ${ }^{57}$

The importance of marriage registration is regulated in Article 5 of KHI which says that in order to guarantee marital order for the Islamic community, every marriage must be recorded. It stresses that marriage registration is only for orderly administration instead as a legal requirement. However, this can't be ignored to make sure that the marriage itself and the parties involved could be well protected and recognized by the state. This is line with what Anshary said about the purpose of recording marriage. For him, it aims to create orderliness in the marriage administration for a good socciety in addition to ensuring the enforcement of rights and obligations for both husband and wife. He also thinks that it is a preventive political law of the state to lead its people in order to create orderliness and well-arranged life system. It is mainly because marriage life is quite

\footnotetext{
55 Aparna Polavarapu, Gendered Dimensions of Marriage and Divorce Registration Laws in Africa, Prepared for Data 2X, UN Foundation, July 28, 2016, 4

56RI Ministry, Compilation of Islamic Law in Indonesiaof Religion, Directorate General of Islamic Institutional Development, Jakarta, 1999, 18.

57 Maruf Amin in Sainul, Urgency of Marriage Registration in Indonesian Laws, http:/ / download.portalgaruda.org/article.php?article=298364\&val=6795\&title=Urge ncy of Marriage Registration in Indonesian Laws
} 
close to any irregularities even disputes between husband and wife. Therefore, the involvement of the authorities/ state in arranging marriages in the form of registration becomes a must. 58

The proof marriage legality is clear from the issuance of an authentic deed namely the marriage certificate (marriage book) on behalf of the bride and groom. A marriage certificate plays is very important because it is the basis for marriage legal guarantees as well as a perfect authentic evidence to provide for any dispute or unexpected condition in the future. This certificate is owned by both husband and wife. Its presence as an official document has many benefits because it has direct implications on the private aspects (civil law) and public law aspects, especially population administration. Thus, the validity of a marriage is very dependent on its record in the administration which integrates to recorded status of the marriage in citizen administration.

In the context of polygamy in Pekalongan, there is only one valid marriage according to the state law because it met the legal requirements and mechanisms. It is marriage between $\mathrm{H} . \mathrm{Mz}$ and his second wife named $\mathrm{Hj}$. Az. On the other hand, 5 other marriages are considered invalid because it was held in sirri procedure. As a consequence of the legal culture of polygamy, the legal status of husband and wife are only applied to the couple $\mathrm{H} . \mathrm{Mz}$ and $\mathrm{Hj}$. Az, while the status for 5 other couples is invalid and considered illegal. For a legal marriage, it obtains a marriage certificate and a right to be registered in the citizeb administration as a family with a family card (KK; Kartu Keluarga). Therefore, 5 other couples do not get marriage certificates and are not considered as husband or wife or family. Neither do they have family cards.

Furthermore, Article 42 of the Marriage Law states that "a legitimate child is a child born in or as a result of a legal marriage". This means that legitimate children will receive legal recognition and protection from the state related to their rights and obligations. The legality proof of the state is through the issuance of birth certificates by mentioning the names of both parents and family cards.

\footnotetext{
58 M. Anshary MK, Marriage Law In Indonesia, Student Library, 2010, 18. See Ahmad Ghufran; Supraptiningsih, Umi;Ferdiant et al., "Empowering Pamekasan to Become a Child-Friendly Regency through Interpersonal Communication" (Atlantis Press, 2018), https://doi.org/10.2991/iccsr-18.2018.36.
} 
Meanwhile, Article 43 Paragraph (1) states that "the children born out of wedlock only have a civil relationship with their mother and mother's family." This provision means that a child born from a polygamous marriage does not have a civil relationship with the father. Therefore, in the birth certificate, there is only the name of a mother. Likewise, there is no father's name on the family card.

The variety of legal culture practiced by informants performing their marriages had an impact on the variety of legal status for husbands, wives and children born in such marriages; some were considered legal but most of them were considered illegitimate. The name of wife in marriage certificate, the child's name on the husband's family card and the child's birth certificate mentioning the name of father and mother are an identification of a legal marriage. Meanwhile, if the second wife's name is not listed in the marriage certificate, the child's name can not be found on the husband's family card and the child's birth certificate only mentions the name of mother are possibly ascertained as unrecorded or illegal marriage.

An unregistered marriage has a very detrimental effect on wife and children. For wives, they are considered illegal because they do not have any marriage certificate as authentic legal evidence. As a result, they will not have any access of gono gini (shared) property when a divorce occurs because the marriage is considered never happen. Additionally, they do not have any legal right for a living cost and inheritance from the husband in the event of divorce or the death of husband. Apart from the legal impact, sirri marriage also causes social impacts for a woman. She will find it difficult to have social interaction because of her stigma as a mistress or living in the same house with a man without getting married (kumpul kebo in Javaness idiom). ${ }^{59}$ The almost same condition occurs to the children of unrecorded polygamous marriage. Although the child is still entitled to a birth certificate and listed on the family card like other children, she/he must psychologically hurt due to the absence of father's name on the birth certificate and family card. Moreover, they will probably get stigmatized as a child out of wedlock, a child of adultery or illegitimate child. In the context of polygamy in Pekalongan, there were 6 children who did not have their father's name on their birth certificate.

${ }^{59}$ Nina Nurmila, ibid., 161. 
The clear information of a child identity has a big impact on his/her status in the marriage which then also correlates to the protection and fulfillment of their civil rights from the father. When the child is born from registered polygamous marriage, his/her legal status is a legitimate child which also means legal recognition and protection of his rights as well as obligations under the marriage law. On the other hand, children from unrecorded polygamy will not receive legal recognition and protection from the state. The civil rights include the right for the fulfillment of daily needs, marriage guardianship and also the inheritance from the father side. Weak protection of any children from sirri marriage is implied in the provisions of Article 55 paragraph (1) which says "the identity of a child can only be proven by an authentic birth certificate issued by authorized official". This birth certificate usually includes the name of the father and mother, but when the certificate of a child from an illegitimate marriage only includes the mother's name.

In Pekalongan context, according to the informants, especially the wife, regardless of the status of either legitimate or illegitimate child, the existence of children in the marriages became very important because they become strong bonds between the husbands and wives. The children could have a strong moral binding power for husbands to provide daily needs for families as well as a moral bond for the wives to survive in the polygamous marriage. This shares the same opinion with what Horowitz said that the presence of children can strengthen a marriage bond more. A married couple feels more satisfied in marriage by looking at the emotional and physical development of children. The presence of children has also encouraged intense communication between husband and wife because they feel experiences living together with their children. Thus, the presence of the children in the family can be seen as a main factor that benefits the parents in terms of psychological, economic and social. ${ }^{60}$

60 A. Horowitz, Sons and Daughters as Cargivers to Older Parents: Differences in Role Performances and Consequences, The Gerontologist 25 (6), 1985, 612-617. Read also Parsudi Suparlan, Kinship System, Family and Role of Men in Descendants, in Anthropology news, Th XIII, No. 46 April-June, 1989. Compare also with Macine Zein and Stanley d. Eitzen, Diversity in Families, 2nd Edition, Harper-Collin, New York, 1990,47 
However, illegitimate status of the children for most informants ( 5 people) who became second wives did indeed become the dominant complaint. They always persuade their husbands to register the marriages, but their wishes were not granted and they can do nothing but surrender. Although psychologically and socially marginalized and underestimated in the society, they generally argue that as long as the husbands are still responsible for meeting the physical and spiritual needs of them and and the children and not sue for any divorce, they felt that it was enough. At the opposite, informants who are the first wives (5 people) said that their husband's unrecorded polygamy marital status made them feel relieved and benefited. Generally, they think that their husband's marital relationships with their second wives are not legal so that the second wives and their children are not entitled to excessively access the husbands' or their joint property. Meanwhile, according to the husbands, unrecorded marriages which then cause their second wives not recognized by the state are not a problem as long as the second wives did not object on it. As the husbands, they simply continue to serve as a head of family and are responsible for the fulfillment of physical and spiritual needs for their wives and children.

\section{Conclusion}

The legal culture of the polygamists in Pekalongan is basically subjective in relation to serious intention to obey the rules of polygamy. The fact shows that the majority of the polygamists' legal culture is negative because they prefer to ignore the rule rather than obey it for pragmatic and rational reasons. Most of the informants acknowledge the difficulty in fulfilling the material normative requirements and procedures regarding polygamous marriage as regulated in statutory regulations and consequently, sirri marriage eventually becomes the most desirable choice.

Polygamy becomes an optional identity politics to foster households which are different from common families which are mostly monogamous. The influencing factors on the optional identity politics are due to pragmatic and rational considerations ranging from factors to non-legal factors such as religion, economic, social and psychology. This optional identity politic finally attachs a negative stigma to both husbands and second wives. 
The type of polygamy cultural practices impacts on the legal statuses of the marriages, husbands, wives, and children; only the first wife and her children are considered legitimate because they are legally recorded while others are illegitimate because not recorded. The evidence of the diverse legal culture of the polygamists is clear from the existence-or absence-of marriage certificate for married couples, the names of second wife and children on the husband's family card, and the names of the father on the child's birth certificate.

\section{Bibliography}

Abdullah, Raihanah Haji. (1999), Poligami di Malaysia, Jurnal Syariah, Bilangan 2

Anshary M., MK. (2010). Hukum Perkawinan Di Indonesia. Jakarta: Pustaka Pelajar.

Choirin, Nur Y.D. (2010). Menyoal Ijin Poligami bagi PNS, Journal Yin Yang. Pusat Studi Gender STAIN Purwokerto, Vol.5 No.2 JuliDes 2010.

Depag RI. (1999). Kompilasi Hukum Islam di Indonesia, Direktorat Jendral Pembinaan Kelembagaan Agama Islam: Jakarta.

Dickson, C. (2007). Marriage and Family Problems. West Publishing Company: Metropolis.

Faisal. (2014). Memahami Hukum Progresif. Yogyakarta: Thafa Media.

Friedman, Lawrence M. (1975). The Legal System A Social Science Prespektif, New York : Russel Sage Foundation.

(1995). "Legal Culture and the Welfare State", in Macaulay, Stewart., Friedman, Lawrence, M. and Stookey, John. Law and Society Reading on the Social Study of Law. New York/London: W.W. Norton and Company.

Giddens, Anthony. (2001). Runway World: Bagaimana Globalisasi Merombak Kehidupan Kita, Jakarta: Gramedia Pustaka Utama.

Poilty Press Ltd.

Hadikusuma, Hilman. (2011). Hukum Perkawinan Indonesia; Hukum Adat, Hukum Agama, 4th edition, Bandung: Mandar Maju.

Hart, H.L.A. (1961). The Consept of Law. Oxford: Oxford University. 
Horowitz, A. (1985). "Sons and Daughters as Caregivers to Older Parents: Differences in Role Performences and Consequences." Journal The Gerontologist. Volume 25. Issue 6.

Irianto, Sulistyowati dkk (editor). (2012). Kajian Socio Legal. Jakarta: Pustaka Larasan.

Berbagai Pilihan Hukum. Jakarta : Yayasan Obor Indonesia.

Jackson, Stevi dan Sue, Scoot. (1996). "Sexual Skirmishes and Feminist Faction" in Feminism and Sexuality: A Reader. New York: Columbia University Press.

Karim, Erna. (2004). "Pendekatan Perceraian Dalam Prespektif Sosiologi", in Buku Bunga Rampai Sosiologi Keluarga, editor: T.O. Irhomi. Jakarta: Yayasan Obor Indoensia.

Kinasih, Sri Endah (2003). "Perkawinan Kontrak di Masyarakat Kalisat", in Jurnal Perempuan No. 29. Mei 2003.

Kolibonso, Rita Serena. (2006). "Diskriminasi itu Bernama Kekerasaan Terhadap Perempuan", in Jurnal Perempuan, 45.

Kompas, Poligami Award: Di Antara Dukungan dan Tantangan. 28 Juli 2003. http ://www.kompas.com/gayahidup/news.

Lev, Daniel S. (2000). Hukum Dan Politik Di Indonesia. Jakarta: Lembaga Penelitian, Pendidikan dan Penerangan Ekonomi dan Sosial (LP3ES).

M., Ibrahim, Muhammad, M. S. I. B. S., \& Samsudin, S. I. B. (2018). "Prosedur Poligami di Malaysia (Analisis AktaUndang-Undang Keluarga Islam Wilayah-Wilayah Persekutuan)", in Samarah: Jurnal Hukum Keluarga dan Hukum Islam, 2(1)

Ma'shum, A.M. M. Khafidz (2017). Persepsi dan Perilaku Ulama Pesisir terhadap Bank Syariah (Studi Terhadap Pembentukan Persepsi dan Perilaku Utama terhadap Bank Syariah Di Pekalogan). Disertasi. Yogyakarta : UIN Sunan Kalijaga.

Macine, Zein dan Stanley d. Eitzen. (1990). Diversity in Families. 2nd edition. New York: Harper-Collin.

Mc. Michael, Philip. (2000). Development and Social Change: A Global Prespective, Pine Forge Press, California.

Munti, Ratna, Batara. (2005). Demokrasi Keintiman Seksualitas di Era Global. Yogyakarta : LKiS.

Mursalin, Supardi. (2007). Menolak Poligami: Studi Tentang UU Perkawinan dan Hukum Islam. Yogyakarta: Pustaka Pelajar. 
Mustafar Farah Wahida dkk, "Konsep Poligami Mengikut Perspektif Para Isteri dalam Jemaah Global Ikhwan Sdn. Bhd", Artikel Available at July 2018. www. Researchgate.Net./ Publication/326225222_Konsep_Poligami_ Mengikut_Perspektif_Para_Isteri_Dalam_Jemaah_Global_Ikhwa n_Sdn_Bhd

Nurhayati. "Kontroversi Poligami".Tempo, XXXV No. 42 (Desember 2006)

Nurmila, Nina. (2009). Women, Islam and Everyday Life: Renegotiating Polygamy in Indonesia. London and New York: Routledge, Taylor and Francis Group.

Poerwanti, Kristi. (2003). "Ilusi Poligami", in Jurnal Perempuan. No. 31. September 2003

Rahardjo, Satjipto. (2003). Sisi-Sisi Hukum Di Indonesia. Jakarta: Penerbit Kompas.

Rahmawati, Rita (2014). "Teologi Buruh: Agama dan Sikap Pasrah Perempuan Buruh Sanggan Batik", in Jurnal Penelitian. Vol. 11. No. 2. November 2014. P3M STAIN Pekalongan

Ramulyo, M. Idris (2000). "Suatu Perbandingan antara Ajaran Syafii dan Wasiat Wajib di Mesir tentang Pembagian Harta Warisan Menurut Islam." Majalah Hukum dan Pembangunan, Nomor 2 Tahun XII.

Rismawati, Shinta Dewi. (2014). Persepsi Poligami di Mata Perempuan Kota Pekalongan. Jurnal Muwazah. Vol. 6 Nomor 2 Edisi Desember 2014

Indonesia (Prespektif Hukum Feminis)”, Jurnal, Vol. 9, No. 2. 2017

Robin, Cohen dan Paul Kennedy. (2000). Global Sociology. London: Maxmillan Press Ltd.

Romli, Dewani. (2010), "Poligami Prespektif Gender" in Al-Adyan Jurnal Studi Lintas Agama, Vol. 5, No 1

Rumadi. "Momentum Reformasi Hukum Keluarga”, in Koran Tempo, (Jakarta). Issued Wednesday, Desember 13, 2006.

Sainul, Urgensi Pencatatan Nikah dalam Perundang-undangan Indonesia. http:/ / download.portalgaruda.org/ article.php?article=298364\& val=6795\&title=Urgensi Pencatatan Nikah Dalam PerundangUndangan Di Indonesia 
Supraptiningsih, Umi;Ferdiant, Ahmad Ghufran;, Erie; Hariyanto, Eka; Susylawati, and Arif Wahyudi. "Empowering Pamekasan to Become a Child-Friendly Regency through Interpersonal Communication." Atlantis Press, 2018. https://doi.org/10.2991/iccsr-18.2018.36.

Setiawati, Effi (2003). "Pengalaman Perempuan dalam Menjalani Kehidupan Perkawinan Nikah Sirri, Studi Kasus di Kecamatan Sumbersari Kabupaten Jember Jawa Timur", in Jurnal Perempuan: Menimbang Poligami. No. 31

Sofiani, Triana. (2016). Perilaku Curang dalam Transaksi Bisnis Batik Di Kota Pekalongan, The 3rd University Research Colloquium. UMS.

Suhanah dan Fauziah. (2011). "Kawin Kontrak di Kawasan Puncak Bogor", in Jurnal Multikultural dan Multireligius. Vol x, No 4. Jakarta : Puslitbang Kehidupan Keagamaan Badan Litbang dan Diklat Kementerian Agama RI.

Suhardana, F.X. (2001). Hukum Perdata I, Jakarta: PT Prenhallindo.

Sundari, Eva, Kusuma. (2004). Perempuan Menguggat. Yogyakarta: Lappera Pustaka Utama.

Suparlan, Parsudi. (1989). Sistem Kekerabatan, Keluarga dan Peranan Pria Dalam Keturunan. Berita Antropologi. Th XIII. No 46 April- Juni, 1989.

Trigiatno, Ali (2013). "Ijin Poligami di Kota Pekalongan", in Jurnal Penelitian. Vol 5 Nomor 1.

W., Katkovsky and Garlow, L. (1986). The Psychology of Adjustment and Competence. USA: Winthrop Publishers Inc.

Wardoyo, Puspo.(2003). Poligami: Kiat Sukses Beristri Banyak (Pengalaman Puspo Wardoyo Bersama 4 Istri. Solo : Bumi Wacana.

Warits Abd. and Abd. Wahed, "Praktik Poligami di Bawah Tangan di Desa Laden Kabupaten Pamekasan", in Al Ihkam Jurnal Hukum dan Pranata Sosial, Vol 9. No 2. 2014,

Wibowo, Brigitta Agni. Relasi Kuasa dalam Komunikasi Keluarga Poligami, (Analisis Kualitatif terhadap Keluarga dengan Relasi Pernikahan Poligami pada Masyarakat Muslim di Kota Pekalongan), diunduh dari http://ejournal.uajy.ac.id/284/1/0KOM03630.pdf

Wignosoebroto, Soetandyo. (2002). Hukum, Paradigma dan Dinamika Masalahnya. Jakarta: Elsam. 